\title{
Planning for the Implementation of the Electronical Neighborhood Unit Application
}

\author{
Eva Zuraidah \\ STMIK Nusa Mandiri / Sistem Informasi \\ JL. Kramat Raya No 18 Jakarta Pusat \\ eva.evz@nusamandiri.ac.id
}

\author{
Jorddy \\ Universitas Bina Sarana Infomatika \\ Jakarta \\ jhordyrrou15@gmail.com
}

\begin{abstract}
Along with the times, digital technology is increasingly developing and all activities will be carried out online because it is considered more practical and fast, and saves time. The neighborhood association is a social organization consisting of several residents and heads of households who have a family card (KK) that are domiciled in the neighborhood (RT) in one neighborhood. Activities within the neighbors include taking care of making boarding house domicile letters (overnight reports), making electronic cover letters of community identification cards to neighborhood residents (RW), making domicile letters and providing information to residents, making dead residents' letters, moving houses. Sometimes activities within the neighborhood also require quite a long time and the process is less efficient. For this reason, an e-government-based website was designed for the neighborhood (RT) neighborhood called the electronic neighborhood (e-Rt). Neighboring electronic units (E-Rt) is a website intended for the residents to access activities in the neighborhood. Making E-RT using MySQL, Php and using the waterfall methodology. From the results of that percentage, the study can match the percentage value with its interpretation criteria. So, the percentage in the first statement has a value of $\mathbf{9 4 . 3 7 5 \%}$ with the statement Agree, With the E-RT application available for making correspondence easier and faster to get in the circle of residents, so there is no effort to come and wait and will save time, also be efficient
\end{abstract}

\section{Keywords - Electronics - Neighborhood (E-RT), Php Mysql, Waterfall}

\section{INTRODUCTION}

Along with developments, times, digital technology is growing and all activities will be carried out online because it is considered more practical and fast, and saves time. Direct administrative services in the neighborhood are many constraints in terms of time, and operationally an ewebsite is created. $\mathrm{rt}$ to facilitate operational services and shorten the time. E-RT

Electronics are in harmony with their neighbors/community groups (e-RT / RW) with the results of the study explaining that the utilization of the e-RT / RW program in Surabaya can be said to be good, the implementation of the program comes from the government as the regulator and facility provider, supported by factor in developing digital concepts. But there are also several inhibiting factors such as lack of public interest, lack of internal support, and facilities and infrastructure that need to be improved. In addition, a forum for intense communication at all levels of society needs to be held, then not just socialization, simulations or practices should be included so that people understand more about the use of online services and also pay attention to the overall evaluation aspects, not just paying attention based on community complaints, but also from aspects of the program and service itself. (Susanti, D, 2018)

The problems that are often faced by the head of the neighborhood unit are Administrative services in the neighborhood, information from residents in the neighborhood, registration of residents in a harmonious environment, management of correspondence in the neighborhood that is still manually computerized. The purpose of making this 
application is to simplify administrative services and make it easier to get citizens' information on the neighborhood pillars digitally through the Electronic website - Rukun Tetangga (e-rt).

\section{Literature REVIEW}

The web is a collection of pages consisting of several pages that contain information in the form of digital data in the form of text, images, video, audio, and other animations provided through internet connection lines. (SALEHA, 2016: 7),

The research method used is the waterfall method. The waterfall model was coined in 1970 as an example of a software development methodology that did not work well (Safitri \& Supriyadi, 2016),

UML is a language, meaning UML has a syntax and systematic. When we make a model using the UML concept some rules must be followed. How the elements in the models that we make relate to one another must follow existing standards (Fajarianto, Iqbal, \& Cahya, 2017: 50).

Web Framework is a combination of components (libraries) and concept design patterns. Web Framework is a software framework specifically designed to support a web application development process. (Sophan, 2016: 1)

Codeigniter is a web framework that is used to develop web applications using the PHP programming language. Codeigniter is widely used by web developers to develop websites or applications. (Putratama, 2016: 1)

Law Number 25 of 2009 concerning Public Services provides the definition: public service is an activity or series of activities in the framework of meeting service needs by the laws and regulations for every citizen and resident of goods, services, and/or administrative services provided by public service providers. (S.AP; M.SI, 2017: 16)

Class Diagrams (Class Diagrams) Is the relationship between classes and detailed explanation of each class in the design model of a system, also shows the rules and responsibilities of entities that determine the behavior of the system. The Class Diagram also shows the attributes and operations of a class and constraints that are related to the object being connected. Class Diagrams typically include Class (Class), Relationship Associations, Generalisation and Aggregation, attributes (Attributes), operations (operation/method) and visibility, the level of access of external objects to an operation or attribute. Relationships between classes have information called Multiplicity or Cardinality. (Windu Gata, 2016)

Use case diagram is modeling for the behavior (behavior) of the information system that will be created. Use cases are used to find out what functions are in the information system and who has the right to use these functions. Symbols used in Use case Diagrams (Windu Gata, 2016)

Activity Diagrams describe workflows (workflows) or activities of a system or business process. Symbols used in Activity Diagrams (Windu Gata, 2016)

E-government is often described differently by each individual or institution. In the scope of countries, understanding the concept of egovernment in a country cannot be separated from the internal conditions of the country concerned. (Primary, Judge, \& Shobaruddin, 2009)

\section{Proposed Method}

This research approach uses a qualitative approach. Because in this study do not isolate individuals or organizations into variables and hypotheses, but view them as part of something wholeness.

The type of research used is qualitative research, namely research that uses a natural setting, to interpret the phenomena that occur and carried out by involving various methods available. The basis of the research is conducted through a survey method through questionnaires that are shared with the community in the neighborhood about activities that are involved in the neighborhood.

The data method or process used is in the form of a waterfall. The shape of the waterfall is as follows:

Figure 1 Data collection techniques using the waterfall method

A. Data collection uses the following techniques:

\section{Using the Test}

The test is an instrument for collecting data and can be divided into 2 :

a. Artificial tests are compiled with certain procedures but have not experienced multiple trials so that their characteristics are unknown. 


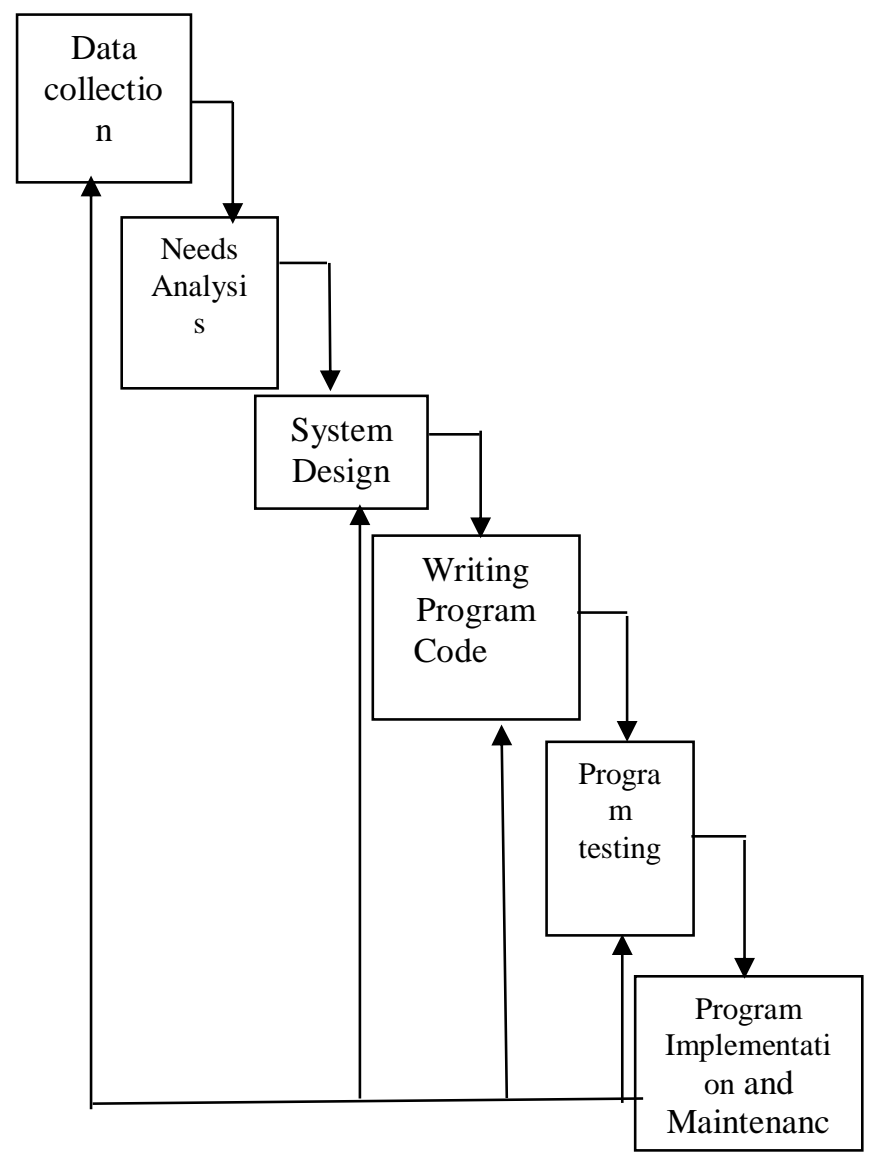

b. Standardized tests are tests that are already available at a testing institution that is guaranteed because they have experienced multiple trials.

\section{Interview}

In conducting interviews, it is necessary to review the interview guidelines. The function of the interview guideline is so that the interview is structured so that there are no main parts left behind and for faster recording. Broadly speaking there are two kinds of interview guidelines:

a. Unstructured interview guidelines, namely interview guidelines that only contain the outline to be asked.

b. Structured interview guidelines, namely interview guidelines arranged in detail so that they resemble a checklist.

\section{Questionnaire}

This questionnaire method has a lot of good as an instrument for collecting data. Before the questionnaire is compiled, it is better to go through the following procedure:

a. Formulate objectives to be achieved by the questionnaire.

b. Identify the variables to be targeted by the questionnaire.

c. Describes each variable to be a more specific sub variable.

d. Determine the type of data to be collected at the same time to determine the type of analysis to be carried out.

B. System Requirements Analysis:

\section{Analysis of Functional Needs}

Functional requirements are the service needs of the application that must be available, the description of the reaction process from the input and what the system will do.

2. Non-Functional Needs are the needs of the devices used in designing and developing an application system.

C. Writing code

Program code writing aims to build a system application program where the programming language and framework have been prepared in advance.

D. Testing

Testing is divided into two, namely black box testing and white box testing. Black box testing is a test that is done by looking at the backend of the application system. Whereas, white box testing is a test that is only seen from the appearance of the application system program.

E. System Implementation and Maintenance

Implementation of the system is done by hosting. System maintenance is done to improve and maintain the system from errors that occur and to improve the application system.

This type of data in the study of erb-based applications uses qualitative research. Data according to the spider is divided into two, namely:

1. Primary data is obtained from the community in the neighborhood of the neighborhood through direct observation of the 
administrative staff of the community in the neighborhood of the neighborhood.

2. Secondary data are taken from administrative service documents in the neighborhood.

\section{RESULT AND DISCUSSION}

A research instrument is a tool used in carrying out data collection. The instrument used for the implementation of this study was a questionnaire. Calculation The questionnaire uses the gudmantt scale using the formula.

The calculation method is to find a percentage, namely:

a. Determine the value weights

For SS answers (Very Often) will be given value 5 .

For answers $\mathrm{S}$ (often) will be given a value of 4.

For answers, CS (Enough S) will be given a value 3

For KK answers (Sometimes) will rated 2.

For TP answers (never) will be given value1.

b. Determine the highest score

The highest number of scores is obtained from the formula highest weight value $\mathrm{x}$ number of respondents $=5 \times 32=160$

c. Determine the interpretation criteria

Figures 0\% - 19.99\% = Never (TP)

Figures $20 \%-39.99 \%=$ Sometimes $(\mathrm{KK})$

Figures $40 \%-59.99 \%$ = Quite often (CS)

Figures $60 \%-79.99 \%=$ Frequently $(\mathrm{S})$

Figures $80 \%-100 \%=$ Very Often (SS)

d. Calculate the percentage

To calculate percentages, we will using the formula: Percentage $=$ Total score $/$ Num highest score $\mathrm{x} 100 \%$

For example we will calculate the value percentage in the 1st statement with using existing formulas. First, let's go we look for the total score, by many citizens who answer $x$ value weights.

Residents who answered SS $=26 \times 5=130$

Residents who answered $\mathrm{S}=3 \times 4=12$

Residents who answered CS $=3 \times 3=9$

Residents who answered KS $=0 \times 2=0$

Residents who answered TS $=0 \times 1=0$

After that, the results of the score are added so get a total score.

Total Score $=130+12+9+0+0=151$
Only after that do we look for value the percentage. Percentage of $\mathrm{P} 1=151 / 160 * 100 \%=94.375 \%$

From the results of that percentage, we can match the percentage value with the interpretation criteria. So, the percentage in the first statement has a value of $94.375 \%$ with the statement Agree.

The study used qualitative research using data collection techniques in the form of: by surveying the head of household on the road Kayumanis Barat NO14 rt 019 / RW 007, Kayumanis sub-district Matraman East Jakarta 13130

This method is used to find a percentage in the next statement.

Table 1 Question for percentage

\begin{tabular}{|c|c|c|c|}
\hline No & Question & Percentage & Description \\
\hline 1. & $\begin{array}{l}\text { Did you feel any } \\
\text { difficulties when } \\
\text { reporting/handli } \\
\text { ng } \\
\text { correspondence } \\
\text { through the local } \\
\text { RT }\end{array}$ & $63 \%$ & Agree \\
\hline 2. & $\begin{array}{l}\text { Do you often not } \\
\text { have time to } \\
\text { come to the RT }\end{array}$ & $60 \%$ & Agree \\
\hline 3. & $\begin{array}{l}\text { Do you often } \\
\text { find it difficult } \\
\text { to contact the } \\
\text { local RT }\end{array}$ & $61 \%$ & Agree \\
\hline 4. & $\begin{array}{l}\text { Do you often } \\
\text { miss } \\
\text { information } \\
\text { from the local } \\
\text { RT }\end{array}$ & $61 \%$ & Agree \\
\hline 5. & $\begin{array}{l}\text { Do you agree if } \\
\text { there is an } \\
\text { increase in your } \\
\text { RT area? }\end{array}$ & $63 \%$ & Agree \\
\hline 6. & $\begin{array}{l}\text { Does the E-RT } \\
\text { application } \\
\text { make it easy for } \\
\text { you to arrange } \\
\text { correspondence }\end{array}$ & $63 \%$ & Agree \\
\hline 7. & $\begin{array}{l}\text { Are you } \\
\text { comfortable } \\
\text { using the E-RT } \\
\text { application }\end{array}$ & $63 \%$ & Agree \\
\hline
\end{tabular}




\begin{tabular}{|l|l|l|l|}
8. & $\begin{array}{l}\text { Does the E-RT } \\
\text { application fit } \\
\text { your needs }\end{array}$ & $61 \%$ & Agree \\
\hline 9. & $\begin{array}{l}\text { After using the } \\
\text { E-RT } \\
\text { application, the } \\
\text { information } \\
\text { submitted by the } \\
\text { RT was clearer }\end{array}$ & $61 \%$ & Agree \\
\hline 10. & $\begin{array}{l}\text { Would you } \\
\text { recommend the } \\
\text { E-RT } \\
\text { application to } \\
\text { your family and } \\
\text { relatives }\end{array}$ & $61 \%$ & Agree \\
\hline
\end{tabular}

As for the method of calculation, it is more or less the same as the previous calculation

a. Weight value as specified previous.

b. The highest number of scores for male citizens is $19 \times 5=95$, while the highest score for female residents is $13 \times 5=65$.

c. The criteria are the same as those previously specified.

d. Use the formula Percentage $=$ Total score / Total highest score $\mathrm{x} 100 \%$ to calculate the percentage of each statement that exists.

e. The results obtained from the calculation are:
Table 2 Results of Calculation of Total Scores

\begin{tabular}{c|c|c|}
\hline Statement & Total Skor & Rercentage \\
\hline P1 & 100 & $63 \%$ \\
\hline P2 & 96 & $60 \%$ \\
\hline P4 & 97 & $61 \%$ \\
\hline P5 & 97 & $61 \%$ \\
\hline P6 & 100 & $63 \%$ \\
\hline P7 & 100 & $63 \%$ \\
\hline P8 & 100 & $63 \%$ \\
\hline P9 & 98 & $61 \%$ \\
\hline P10 & 97 & $61 \%$ \\
\hline
\end{tabular}

Conduct interviews about administrative activities, how citizens get information and know the management data rt. Questionnaire in the form of questions about the application of e-RT and activities carried out in the neighborhood. The way to calculate yourself using the Gutman scale is: 


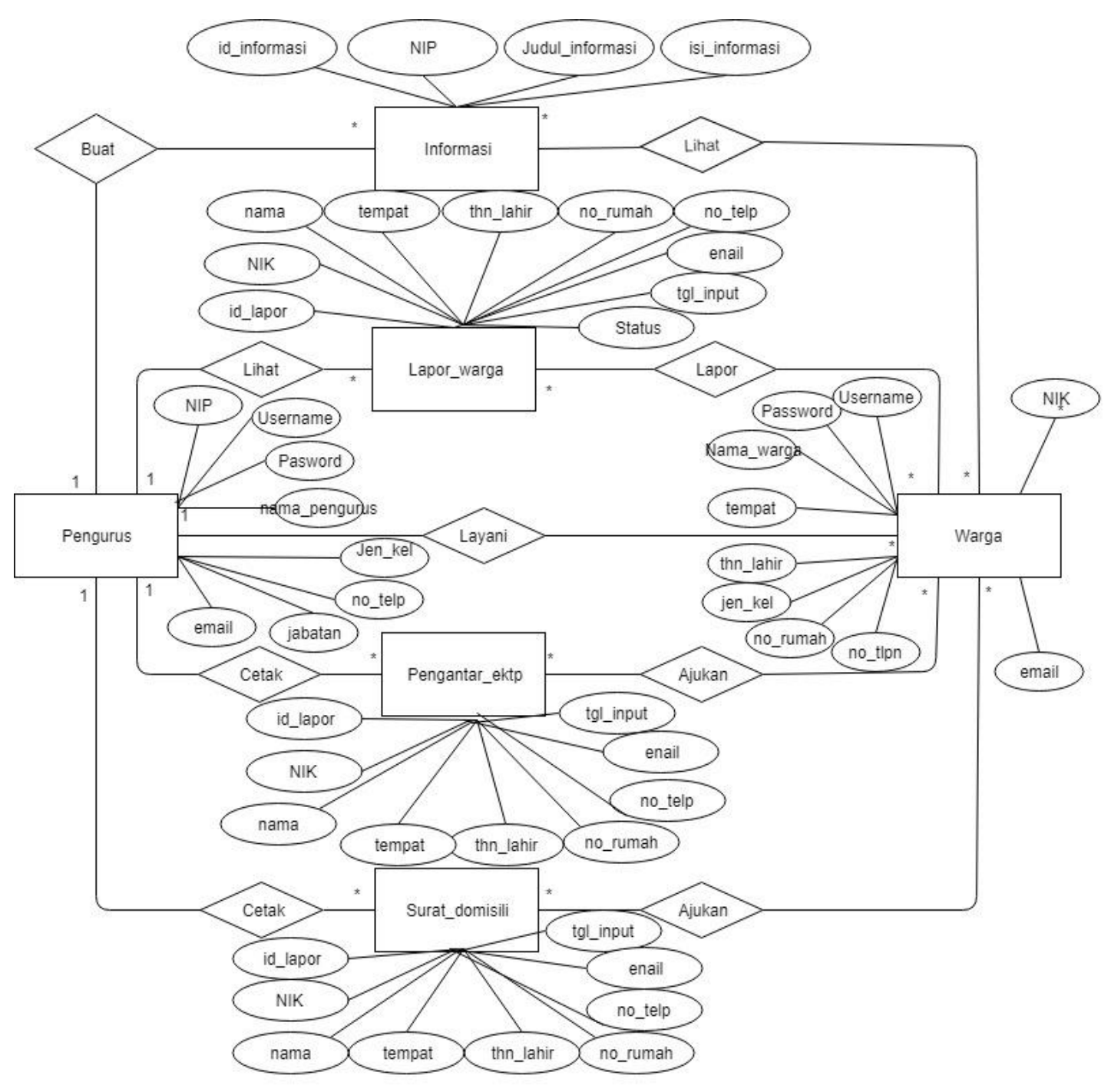

Figure 2 Entity Relationship Diagram 


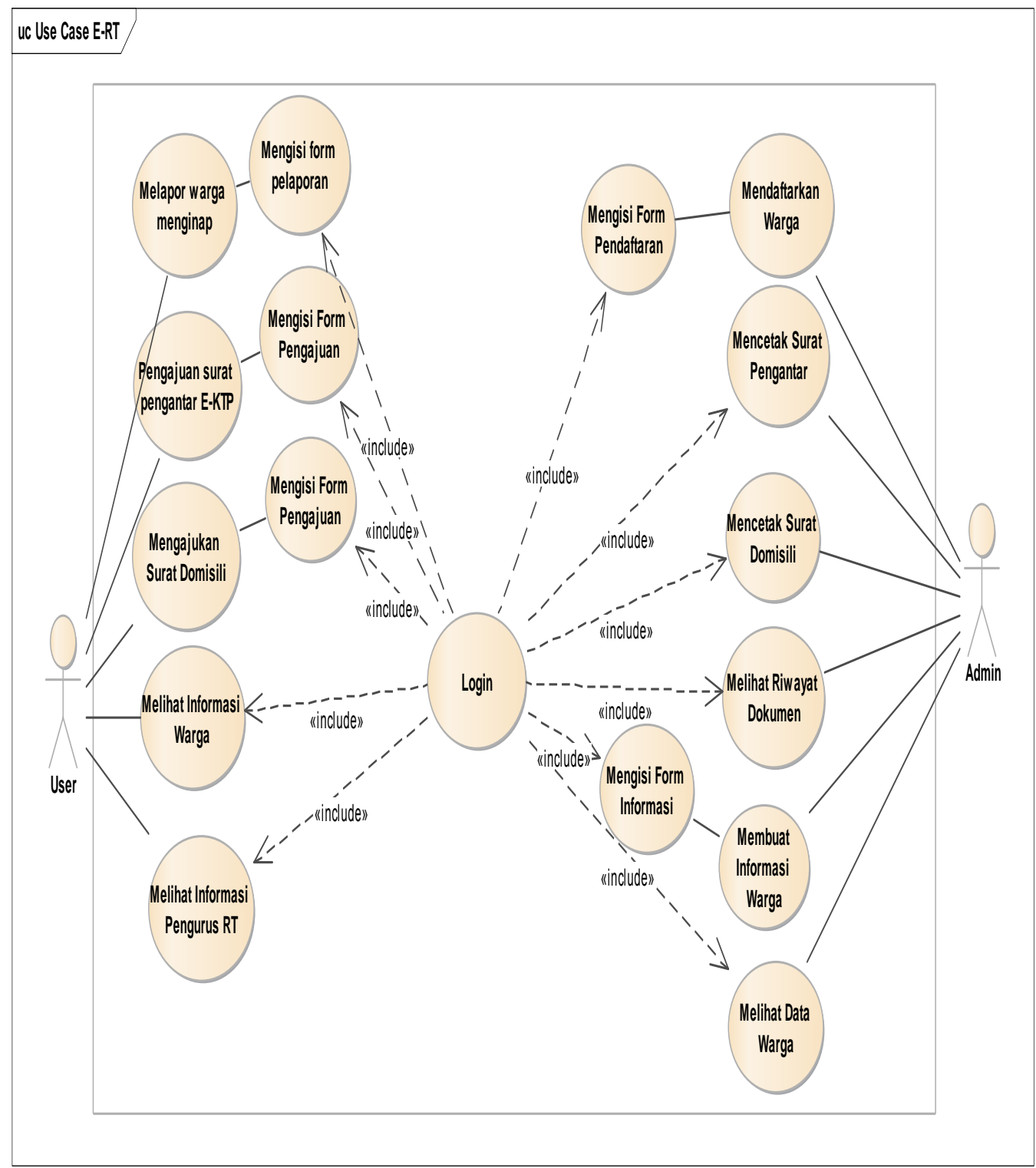

Figure 3 Use case Diagram Aplikasi e-rt 


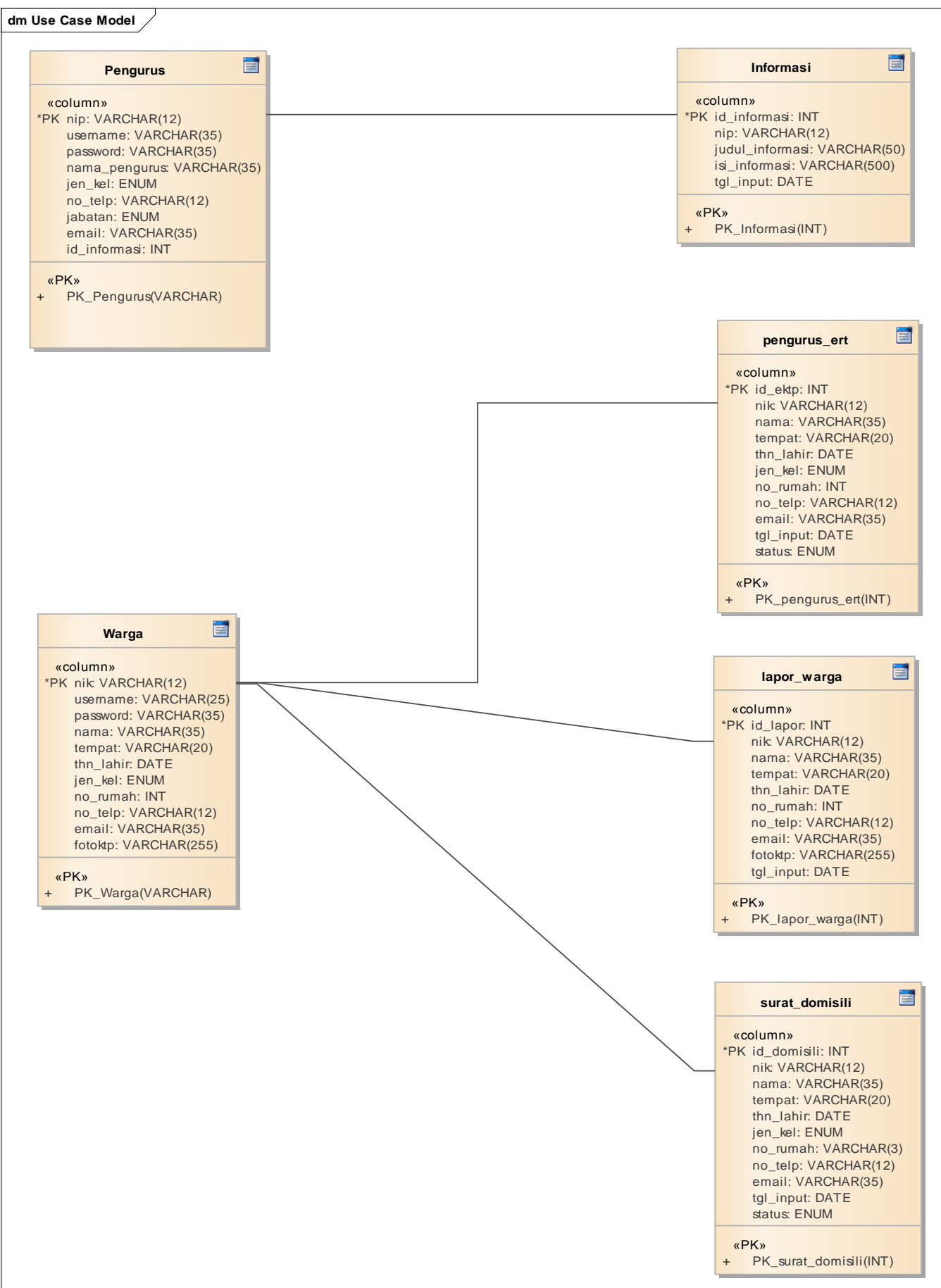

Relationship System

Figure 4.Logical 


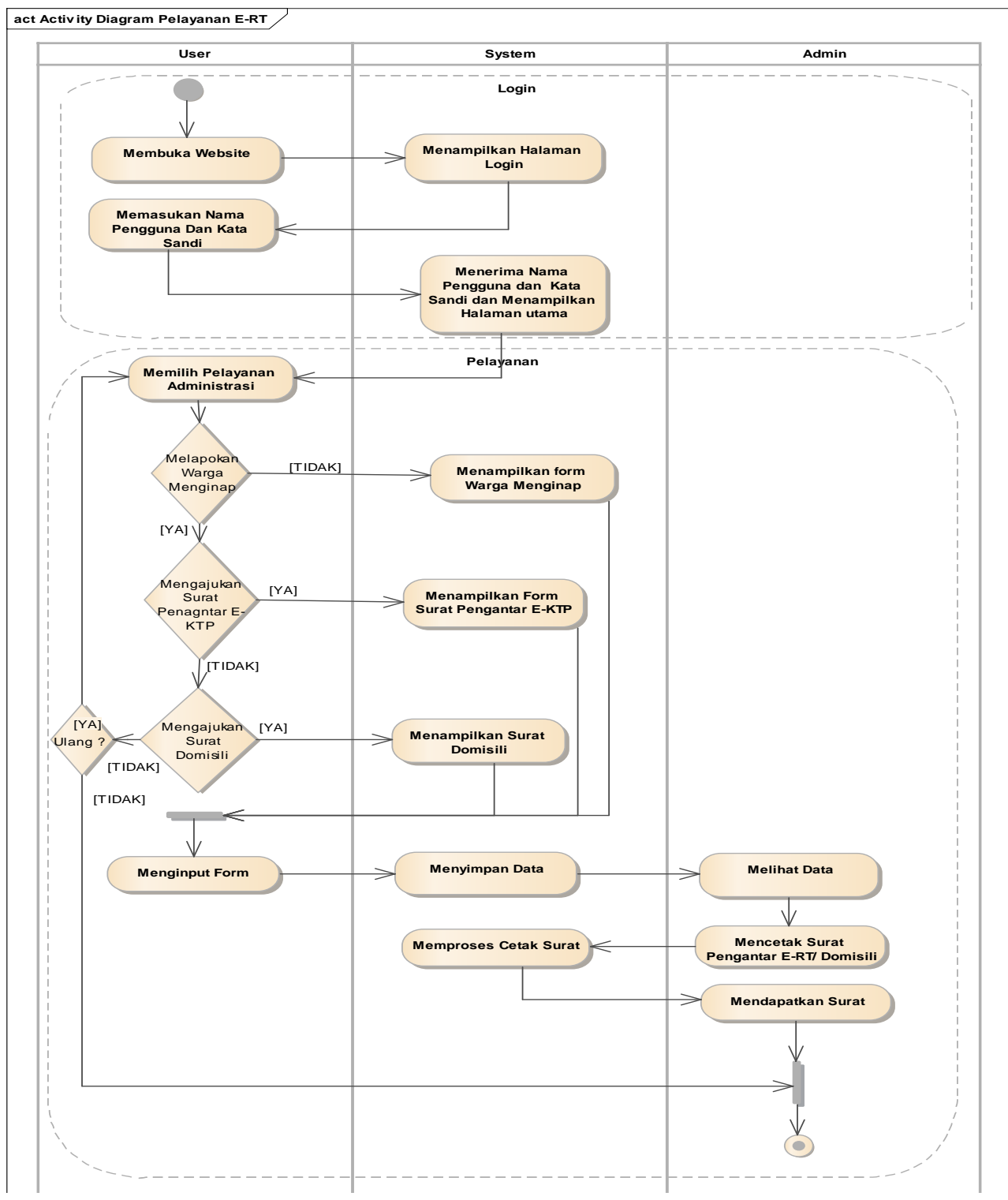

Gambar 5 Activity Diagram Aplikasi e-rt 


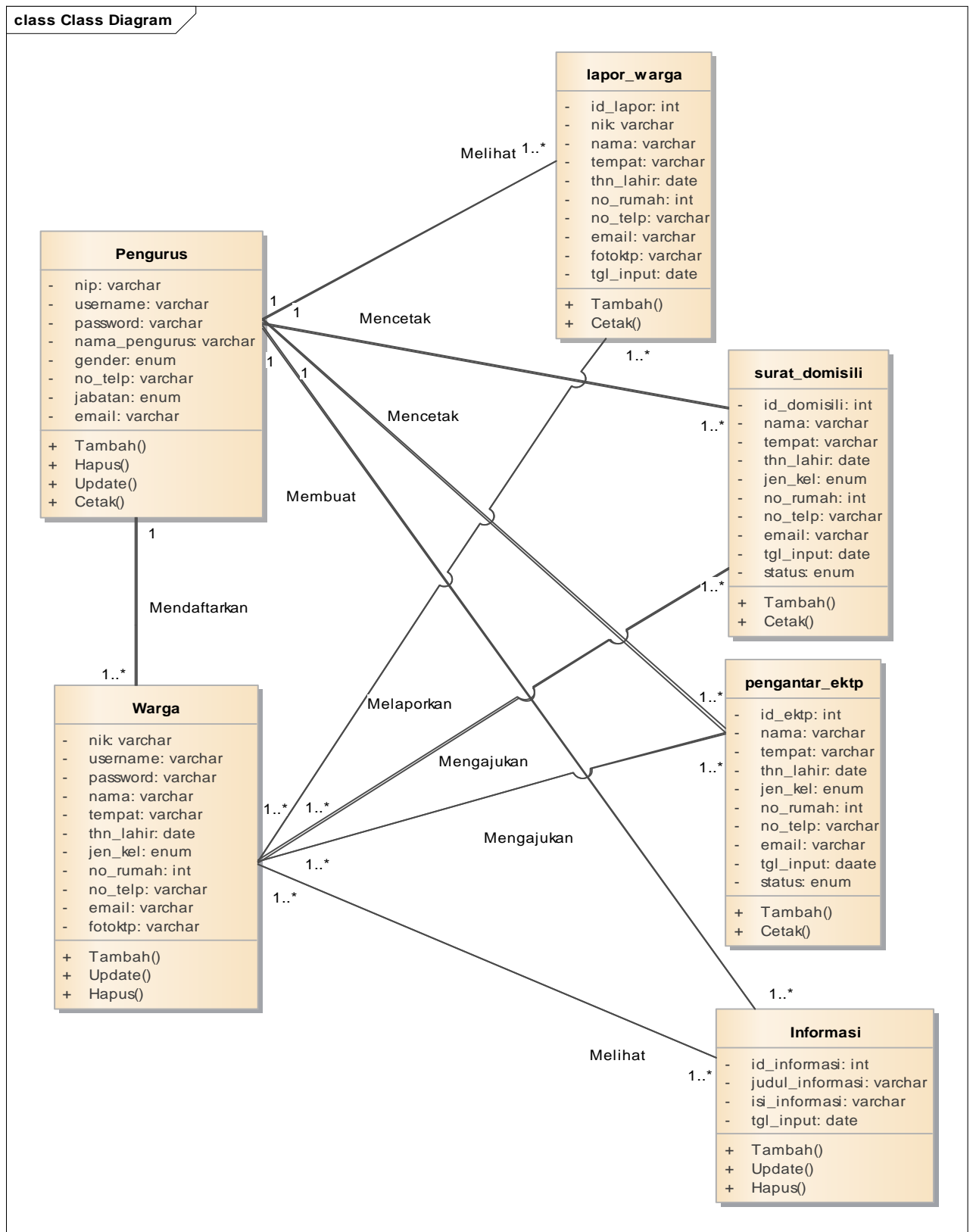

Figure 6. Class diagram Aplikasi E-Rt 


\section{Cin Journal Publications \& Informatics Engineering Research \\ Volume 4, Number 1, October 2019 \\ DOI : https://doi.org/10.33395/sinkron.v4i1.10136

The e-RT application prototype includes:

A. Display Admin Design:

1. Admin Login

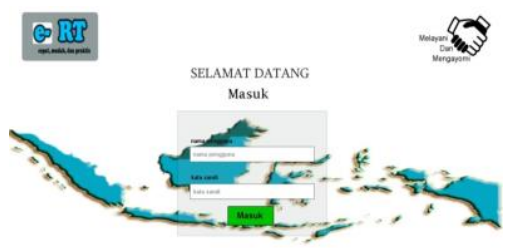

FIGURE 7 ADMIN LOGIN

2. Admin Main Page

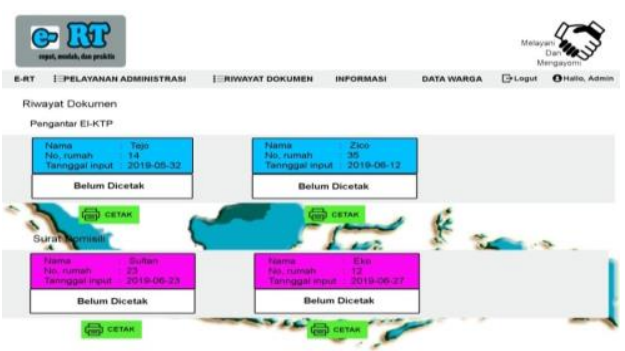

Figure 8 Admin Min Page

3. Document History.

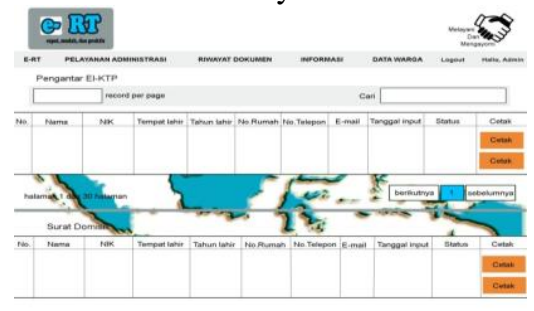

Figure 9 Document History.

4. Admin Information

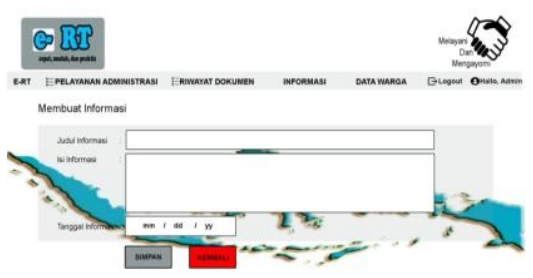

Figure 10 Admin Information
5. AdD Citizens.

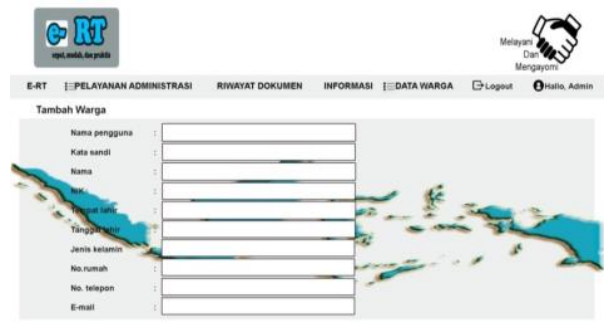

FIGURE 11 ADD CITIZENS

\section{CONCLUSION AND SUGGESTION}

\section{Conclusion}

This E-RT application was made to make it easier for people in the neighborhood to carry out administrative activities, to obtain information about citizens, and to know the management of letters to residents in neighborhoods efficiently and effectively because they use technology that can be accessed anywhere. This E-RT application still uses websites using sublime as a text editor, PHP as the programming language, and Codeigniter as its framework.

This study uses a type of qualitative research and a qualitative approach where data collection uses the waterfall method and uses a questionnaire whose calculations use the Gutman scale.

Diagrams for keeping the flow and compiler of the E-RT application database. The diagram in question includes ERD, LRS, use case, activity, and class diagrams. The description for the e-RT application display is discussed in full, solid and clear in the E-RT application display section.

\section{Suggestion}

There are still many shortcomings in this application, for the future to be more detailed and use different techniques in calculating questionnaires with different results but with the same meaning

\section{REFERENCES}

Fajarianto, O., Iqbal, M., \& Cahya, J. T. (2017). Sistem Penunjang Keputusan Seleksi Penerimaan Karyawan Dengan Metode Weighted Product. Jurnal Sisfotek Global, 7(1), 49-55.

Pratama, R. H., Hakim, A., \& Shobaruddin, M. (2009). Pelayanan Publik Berbasis Teknologi Informasi Dan Komunikasi (TIK), Elektronik 
Putratama, S. dan V. (2016). Pemrograman web dengan menggunakan PHP dan FRAMEWORK CODEIGNITER (1 ed.; H. R. dan C. M. Sartono, ed.). Yogyakarta: Deepublish.

Rukun Tetangga/Rukun Warga (e-RT/RW) (Studi eGovernment di Kelurahan Ketintang Kecamatan Gayungan Pemerintah Kota Surabaya). Jurnal Administrasi Publik (JAP), 3(12), 2128-2132

SALEHA, D. U. M. I. (2016). Aplikasi Pemesanan Perumahan Ogan Permata Indah Berbasis Web Pada Pt. Sekawan Kontrindo. 7-22.

Sophan, M. K. (2016). Pengembangan Aplikasi WEB Menggunakan CODEIGNITER Konsep dan Implementasi (Cetakan Pe). Yogyakarta: Deepublish.

Suhaidi, M. (2016). Konsep Dasar Pemrorgraman $W E B$ dengan PHP dan MYSQL (cet-1; herlambang Rahmadhani dan Cintia Morris
Sartono, ed.). Yogyakarta: Deepublish. Susanti, D. (2018). YANG BERDAMPAK TERHADAP PELAYANANAN KEPADA MASYARAKAT ( STUDI KASUS PADA POLSEK SUKAHAJI ). 4, 1-6.

S.AP;M.SI, H. (2017). MANAJEMEN PELAYANAN PUBLIK (Cetakan Ke). Depok: PT RajaGrafindo Persada.

Windu Gata, G. (2016). Pemodelan UML sistem informasi Monitoring Penjualan dan stok barang. Pemodelan Uml Sistem Informasi Monitoring Penjualan Dan Stok Barang (Studi Kasus: Distro Zhezha Pontianak), IV(2), 107116.

https://doi.org/10.2135/cropsci1983.0011183X $002300020002 x$ 